\title{
INTERAKSI SOSIAL ORANG DENGAN HIV DENGAN \\ LINGKUNGAN SOSIAL DI LEMBAGA SWADAYA \\ MASYARAKAT WISMA KABUPATEN CIAMIS
}

\author{
Salma Fathia Nada \\ Politeknik Kesejahteraan Sosial Bandung \\ Teta Riasih \\ Politeknik Kesejahteraan Sosial Bandung,tetariasih@yahoo.com
}

\begin{abstract}
Social interaction is one of the problems for people with HIV. Social interaction is useful for them to do their social functioning. The purpose of this research is to describe how people with HIV can do the social interaction in their social environment, with aspects of situations and actions within the family, neighbors, friends, and officers/officials of NGOs. The method is descriptive with quantitative approach. Sampling use the saturated sample. Data collection techniques were conducted using questionnaires, observations, and documentation studies to 40 people with HIV. Validity use the face validity. Reliability using Alpha Cronbach formula through SPSS calculations. Data analysis uses data processing, tabulation, and data interpretation. The results describe the overall social interactions of people with HIV, including high. Five aspects of social interaction are in the high category and three aspects are in the medium category. It shows that respondents already know to behave when doing social interaction.
\end{abstract}

Keywords: People with HIV, Social Interaction, Social Environment

\begin{abstract}
ABSTRAK
Interaksi sosial merupakan salah satu permasalahan yang sedang dihadapi oleh orang dengan HIV. Interaksi sosial berguna dalam melaksanakan keberfungsian sosial. Penelitian ini bertujuan untuk menggambarkan bagaimana interaksi sosial yang dilakukan orang dengan HIV dengan lingkungan sosialnya yang mencakup aspek situasi dan aksi di lingkungan keluarga, tetangga, teman, dan petugas/pengurus LSM. Metode penelitian yang digunakan adalah penelitian deskriptif dengan pendekatan kuantitatif. Teknik pengumpulan data dilakukan dengan menggunakan kuisioner, observasi, dan studi dokumentasi kepada 40 orang dengan HIV. Validitas yang digunakan adalah validitas muka. Reliabilitasnya menggunakan rumus Alpha Cronbach melalui perhitungan SPSS. Analisis data menggunakan pemrosesan data, tabulasi, dan penafsiran data. Hasil penelitian menggambarkan interaksi sosial orang dengan HIV keseluruhan termasuk tinggi. Lima aspek interaksi sosial berada pada kategori tinggi dan tiga aspek berada dalam kategori sedang. Hal tersebut menunjukkan bahwa responden sudah tahu harus bersikap ketika melakukan interaksi sosial.
\end{abstract}

Kata Kunci: Interaksi Sosial, Lingkungan Sosial, Orang dengan HIV 


\section{PENDAHULUAN}

Permasalahan mengenai Human Immunodeficiency Virus yang selanjutnya disingkat menjadi HIV merupakan masalah kesehatan yang mengancam banyak negara di seluruh dunia termasuk Indonesia. Menurut Kementerian Negara Pemberdayaan Perempuan dan Perlindungan Anak RI (2016), kasus HIV yang terjadi di Indonesia semakin meningkat dari tahun ke tahun, bahkan kasus tersebut dapat dikatakan fenomena gunung es, dimana jumlah yang tercatat lebih sedikit daripada kasus yang sebenarnya.

Data yang tercatat oleh Komisi Penanggulangan AIDS sesuai dari laporan Kementerian Kesehatan Republik Indonesia triwulan 2 Bulan April hingga Juni 2016, pada Tahun 2011 sebanyak 21.031 kasus, kemudian Tahun berikutnya menjadi sebanyak 21.511 kasus, pada Tahun 2013 tercatat sebanyak 29.037 kasus, Tahun 2014 sebanyak 32.711 kasus, Tahun 2015 sebanyak 30.935 kasus dan hingga Bulan Juni 2016 tercatat sebanyak 17.874 kasus. Lima daerah dengan kasus HIV tertinggi adalah Provinsi DKI Jakarta dimana tercatat 40.500 kasus, diikuti oleh Jawa Timur sebanyak 26.052 kasus, Papua sebanyak 21.474 kasus, Jawa Barat sebanyak 18.727 kasus serta Jawa Tengah sebanyak 13.547 kasus.

Pencatatan kasus yang setiap tahunnya bertambah ini didasari atas penularan HIV terjadi begitu cepat di masyarakat. Ketidakpahaman mengenai penularan HIV hingga mitos yang beredar di masyarakat semakin membuat informasi yang disebarkan menjadi lebih simpang siur. Salah satu mitos yang beredar di masyarakat adalah HIV bisa tertular melalui sentuhan fisik. Hal ini menjadi suatu permasalahan lain yang timbul di masyarakat, dimana ketika ada salah satu anggota masyarakatnya yang terinfeksi HIV, maka akan dijauhi dan bahkan dikucilkan akibat HIV tersebut.

Permasalahan HIV selain memberikan respon terhadap masyarakat, juga memberikan dampak yang sangat kompleks terhadap orang dengan HIV. Dampak-dampak yang dirasakan yaitu penderitaan secara fisik, psikis, sosial, ekonomi, dan spiritual. Harry Hikmat (2015) dalam Artikel staf Ahli Bidang Dampak Sosial kemudian menyatakan bahwa "orang dengan HIV akan berhubungan dengan stigma dan diskriminasi dalam bentuk prasangka berlebihan, sikap yang negatif, dan perlakukan salah secara langsung dari orangorang sekitarnya”. Konsekuensi dari stigma dan diskriminasi, orang dengan HIV menarik diri dari lingkungan keluarga, kelompok pertemanan, dan komunitas sekitarnya. Dalam hal ini, penulis dapat menjelaskan bahwa penderitaan secara psikis, perlakuan diskriminatif, prasangka buruk, pemberian stigma hingga penolakan maupun pengucilan terhadap orang dengan HIV membuat mereka menjadi dalam kondisi yang lebih tertekan. 
Sikap negatif dari masyarakat, lingkungan sekitar, hingga stigma yang beredar membuat kondisi orang dengan HIV menjadi jauh lebih mengkhawatirkan. Di Indonesia masih banyak penolakan atau pengucilan yang di terima oleh penyandang HIV baik oleh keluarganya sendiri dan masyarakat sekitar. Pemberian stigma negatif oleh masyarakat biasanya dikarenakan oleh faktor-faktor yang menjadi penyebab penularan HIV. Padahal saat ini, orang yang terinfeksi HIV bukan hanya orang-orang yang berisiko saja, tetapi juga pada kelompok yang semula dianggap rentan seperti perempuan ibu rumah tangga dan balita.

Berdasarkan identifikasi penulis dari koransindo.com, sikap negatif maupun stigma dari masyarakat tersebut dapat mengakibatkan penyandang HIV merahasiakan kondisinya dengan berusaha menutup diri dari lingkungan masyarakat setempat, dimana sudah pasti akan menambah berat beban psikososial mereka. Masyarakat akan mengganggap bahwa orang yang terinfeksi HIV adalah aib, perlu dijauhi sehingga orang dengan HIV pada akhirnya akan memiliki perasaan ragu, takut, hingga curiga kepada orang lain yang berada dekat dengan dirinya dan lambat laun mereka mulai menutup dirinya dalam melakukan interaksi. Padahal, dalam kehidupan sehari-hari mereka juga perlu berinteraksi dengan lingkungan sosial dalam memenuhi kebutuhan hingga mengatasi hambatan yang dirasakannya.

Bonner dalam Slamet Santoso (2014) menjelaskan bahwa interaksi sosial adalah suatu hubungan antara dua orang atau lebih individu dimana kelakuan individu yang satu mempengaruhi, mengubah, atau memperbaiki kelakuan individu yang lain atau sebaliknya. Dalam hal ini, Bonner menekankan tentang proses hubungan antara dua orang atau lebih individu yang berada dalam situasi yang sama yaitu situasi sosial.

Robert F. Bales (dalam Santoso:2014) mengemukakan mengenai aspek-aspek yang dapat dijadikan tolak ukur dari interaksi sosial. Aspek tersebut terdiri dari situasi dan aksi. Situasi adalah suasana dimana proses interaksi sosial itu berlangsung dan masingmasing individu menunjukkan tingkah lakunya, sedangkan aksi adalah suatu tingkah laku dari individu yang tampak dan merupakan pernyataan kepribadian individuindividu tersebut.

Orang dengan HIV memiliki permasalahan psikologis dengan dirinya sendiri, baik itu berupa perasaan ragu, takut, bahkan curiga terhadap orang lain yang ada di sekitarnya. Hal tersebut disebabkan karena stigma dan diskriminasi terhadap orang dengan HIV di masyarakat masih sangat tinggi. Padahal, secara penampilan fisik, tidak dapat dibedakan dengan langsung mana saja orang yang terinfeksi HIV dan mana orang yang tidak terinfeksi HIV. Orang dengan 
HIV memang memiliki keterbatasan, hal ini dimaksudkan bahwa mereka memang mudah terjangkit penyakit dikarenakan sistem kekebalan tubuhnya yang berbeda. Akan tetapi, hal tersebut bukanlah alasan yang menjadikannya tidak berinteraksi dengan masyarakat yang lebih luas.

Interaksi sosial penting dilakukan karena ketika orang berinteraksi akan membantu mengatasi masalah dan hambatan serta dapat memenuhi kebutuhan sehari-hari. Berdasarkan pemaparan interaksi sosial menurut Bonner, orang dengan HIV dapat mempengaruhi dan dipengaruhi perilakunya oleh orang lain, dapat mengubah dan diubah perilakunya oleh orang lain, serta dapat memperbaiki dan diperbaiki perilakunya oleh orang lain. Ketika orang dengan HIV tidak melakukan interaksi sosial, maka dia tidak mendapatkan klarifikasi dan justifikasi yang dibutuhkannya. Orang dengan HIV yang menutup diri dari lingkungan sosialnya dan melakukan berbagai kegiatan sendirian akan memunculkan self-talk dan interaksi sosialnya menjadi tidak seimbang.

Lembaga Swadaya Masyarakat Wisma Kabupaten Ciamis, yang kemudian disingkat penulisannya menjadi LSM WISMA Ciamis, merupakan salah satu LSM yang aktif bergerak di bidang sosial, terutama pada pencegahan HIV. Cakupan wilayah penjangkauan dari LSM WISMA sangat luas, dimana LSM ini merangkul kelompok berisiko tertular HIV di wilayah Ciamis. Kelompok berisiko ini terdiri dari wanita-pria (waria), pengguna narkoba jarum suntik (penasun), homoseks terutama laki-laki yang berhubungan seks dengan laki-laki (LSL), serta ibu rumah tangga (IRT). Dalam proses penjajakan dan hasil pengamatan sementara, LSM WISMA menyatakan bahwa terdapat sebanyak 259 orang dengan HIV atau AIDS dari total penduduk Ciamis yang kurang lebih berjumlah sebanyak 154.000 orang, dimana data ini merupakan kumulatif hingga Bulan November 2018.

Kegiatan yang dilakukan oleh LSM WISMA dalam bidang HIV ini diantaranya dengan melakukan penyuluhan, skrining, dan mobile VCT yang dilakukannya dengan bekerja sama dengan instansi pemerintah baik itu Dinas Sosial maupun Dinas Kesehatan. Selain itu, LSM WISMA juga memiliki kelompok dukungan sebaya yang lebih dikenal dengan Ciamis Care Support (CCS) dimana kemudian mereka saling bekerja sama. Dalam kegiatannya, orang dengan HIV ini dapat berkumpul dalam setiap sesi yang diadakan oleh pendamping, menceritakan bagaimana kehidupannya saat ini, melakukan kunjungan rumah maupun kunjungan rumah sakit dan juga melakukan interaksi sosial dalam lingkungan CCS.

Orang dengan HIV yang berada di bawah naungan LSM WISMA bersama CCS ini menunjukkan sikap yang masih menutup diri dalam berinteraksi sosial di lingkungan 
sosial lainnya, yang ditunjukkan oleh salah satu informan, dimana menceritakan bahwa dia tidak mau mengambil ARV, jika dia mau mengambil ARV harus dibawakan oleh petugas LSM maupun pendamping, dan bahkan ketika berada di rumah hanya mengurung diri saja, menyimpan ARV dalam tempat yang sangat tersembunyi bahkan terkadang sengaja melewatkan jam untuk meminum ARV, seakan-akan dia sudah tahu dengan pasti bahwa siapapun yang berada di sekitar lingkungan rumahnya sudah mengetahui bahwa dia adalah seorang yang terinfeksi HIV.

Melihat dari permasalahannya, jika orang dengan HIV menarik diri dalam melakukan interaksi sosial dan keadaan lingkungan sosial juga tidak mendukung mereka, akan muncul dampak buruk untuk orang dengan HIV tersebut. Orang dengan HIV tidak akan dapat melaksanakan keberfungsian sosialnya secara wajar. Akan tetapi, jika orang dengan HIV mampu melakukan interaksi dengan baik maka mereka dapat melakukan aktivitas, berinteraksi dengan lingkungan sosialnya seolah-olah bahwa terinfeksi HIV bukanlah suatu halangan untuk mencapai keberfungsian sosial mereka.

Berdasarkan penjelasan sebelumnya, peneliti dapat menyimpulkan bahwa tujuan diadakannya penelitian ini adalah untuk menggambarkan interaksi sosial yang dilakukan oleh orang dengan HIV dengan lingkungan sosialnya di LSM WISMA yangg terdiri dari a) Karakteristik orang dengan HIV; b) Situasi orang dengan HIV dalam berinteraksi sosial dengan lingkungan keluarga; c) Situasi orang dengan HIV dalam berinteraksi sosial dengan lingkungan tetangga; d) Situasi orang dengan HIV dalam berinteraksi sosial dengan lingkungan teman; e) Situasi orang dengan HIV dalam berinteraksi sosial dengan petugas/pengurus LSM; f) Aksi orang dengan HIV dalam berinteraksi sosial dengan lingkungan keluarga; g) Aksi orang dengan HIV dalam berinteraksi sosial dengan lingkungan tetangga; $h$ ) Aksi orang dengan HIV dalam berinteraksi sosial dengan lingkungan teman; dan i) Aksi orang dengan HIV dalam berinteraksi sosial dengan petugas/pengurus LSM.

\section{METODE}

Penelitian ini menggunakan pendekatan kuantitatif dengan metode deskriptif. Penelitian deskriptif kuantitatif ini digunakan untuk menggambarkan dengan lebih teliti ciri-ciri individu maupun situasi yang digambarkan. Menurut Burhan Bungin (2014) penelitian kuantitatif deskriptif dimaksud hanya untuk menggambarkan, menjelaskan, atau meringkaskan berbagai kondisi, situasi, fenomena, atau berbagai variabel penelitian menurut kejadian sebagaimana adanya yang dapat dipotret, diwawancara, diobservasi, serta yang dapat diungkapkan melalui bahan-bahan dokumenter.

Adapun yang dimaksud interaksi sosial dalam penelitian ini adalah 
situasi dan aksi yang dilakukan oleh dua individu atau lebih yang mempengaruhi satu sama lain sehingga dapat mempengaruhi, mengubah, atau memperbaiki indivdu yang lainnya. Interaksi sosial dapat diukur berdasarkan aspek-aspek interaksi sosial, yaitu a) Situasi yang dimaksud adalah suasana dimana proses interaksi itu berlangsung dan masing-masing individu menunjukkan tingkah lakunya. Situasi bisa terlihat dimana adanya keterlibatan dengan orang lain, keterlibatan dengan berbagai kegiatan, serta ketergantungan terhadap orang lain; dan b) Aksi yang dimaksud adalah tingkah laku yang ditampilkan individu yang tampak dan merupakan pernyataan kepribadian individu-individu tersebut. Aksi bisa terlihat dimana orang dengan HIV mampu melakukan komunikasi verbal, kontak mata, menunjukkan perilaku yang tepat, serta memberikan respon terhadap orang yang dianggap mempunyai figur/jabatan. Orang dengan HIV yang dimaksud adalah seorang laki-laki maupun perempuan yang telah terinfeksi HIV. Dalam penelitian ini, ODH yang dimaksud berada dalam lingkungan LSM WISMA Kabupaten Ciamis yang berusia 18 tahun atau lebih.

Populasi dalam penelitian ini adalah jumlah Orang dengan HIV yang berada di LSM WISMA dan dapat dijangkau oleh kelompok dukungan sebaya sebanyak 40 orang dimana berusia 18 hingga 60 dengan berbagai faktor risiko. Sedangkan untuk menentukan jumlah sampel digunakan teknik sampling jenuh. Menurut Sugiyono (2011), teknik sampling jenuh adalah teknik penentuan sampel bila jumlah populasi relatif kecil, kurang dari 30 orang, atau penelitian yang ingin membuat generalisasi dengan kesalahan yang sangat kecil. Istilah lain sampel jenuh adalah sensus, dimana semua anggota populasi dijadikan sampel. Sehingga, jumlah sampel adalah sebanyak jumlah populasi itu sendiri sebanyak 40 orang responden.

Dalam menerapkan metode penelitian kuantitatif ini, peneliti menggunakan teknik pengumpulan data yang terdiri dari kuisioner/angket, observasi, dan studi dokumentasi. Kuisioner yang digunakan oleh peneliti didasarkan pada Social Interaction Scale (BaFPE) yang disusun oleh Susan Lang Williams dan Judith S. Bloomer pada tahun 1987, kemudian diadaptasikan dan dimodifikasi untuk responden yang berada di LSM WISMA Kabupaten Ciamis untuk melihat bagaimana interaksi sosial yang mereka lakukan. Observasi atau pengamatan adalah kegiatan keseharian manusia dengan menggunakan pancaindra mata sebagai alat bantu utamanya selain pancaindra lainnya seperti telinga, penciuman, mulut, dan kulit. Teknik ini didasarkan atas pengalaman secara langsung dan memungkinkan peneliti melihat dan mengamati sendiri, kemudian mencatat perilaku dan kejadian sebagaimana yang terjadi 
pada keadaan yang sebenarnya. Observasi yang dilakukan peneliti adalah observasi non-partisipan. Kegiatan observasi ini dilakukan dengan cara melihat bagaimana keadaan dan tingkah laku responden dalam melakukan kegiatan terutama yang berkaitan dengan aspek-aspek interaksi sosial yang dijadikan bahan penilaian dalam pedoman observasi yang terdiri dari situasi dan aksi di lingkungan keluarga, lingkungan tetangga, lingkungan teman, dan lingkungan bersama petugas/ pengurus LSM. Studi dokumentasi yaitu teknik pengumpulan data dilakukan dengan mempelajari literatur-literatur, mengambil gambar atau foto-foto, laporan, file, atau arsip yang berhubungan dengan permasalahan penelitian. Dalam studi dokumentasi ini berisi tentang profil LSM WISMA Kabupaten Ciamis dan kegiatan orang dengan HIV dalam melakukan interaksi sosial dalam berbagai aspek.

Alat ukur yang digunakan dalam penelitian tentang interaksi sosial orang dengan HIV/AIDS terhadap lingkungan sosial di LSM WISMA Kabupaten Ciamis adalah Social Interaction Scale (BaFPE) dengan menggunakan skala likert. Skala likert digunakan untuk mengukur sikap, pendapat, dan persepsi seseorang atau sekelompok orang tentang fenomena sosial (Sugiyono, 2011). Dengan skala likert, maka variabel yang diukur dijabarkan menjadi indikator variabel. Kemudian, indikator tersebut dijadikan sebagai titik tolak untuk menyusun item-item instrumen yang dapat berupa pernyataan atau pertanyaan.

Penelitian ini menggunakan validitas muka. Menurut Moh. Nazir (2011) validitas muka berhubungan dengan penilaian para ahli terhadap suatu alat ukur. Uji validitas muka dilakukan dengan cara mengkonsultasikan kebenaran alat ukur dengan dosen pembimbing, sebelum instrumen digunakan untuk mengumpulkan data. Sedangkan reliabilitas yang digunakan adalah rumus Alpha Cronbach. Pengujian reliabilitas tidak dilakukan perhitungan secara manual tetapi menggunakan Statistical Product and Service Solution (SPSS). Hasil yang didapatkan melalui perhitungan reliabilitas Alpha Cronbach melalui Statistical Product and Service Solution (SPSS) adalah senilai 0,983. Berdasarkan tabel interpretasi nilai $\mathrm{r}$ dalam Suharsimi Arikunto (2014), maka intrumen penelitian yang digunakan oleh peneliti adalah berada dalam interval 0,800-1,000 yang merupakan sangat tinggi dan dapat digunakan dalam mengukur interaksi sosial dengan aspek situasi dan aksi.

Langkah-langkah yang dilakukan peneliti dalam melakukan pengolahan dan analisis data adalah:

1. Menyiapkan data dan melakukan pemeriksaan (editing); proses ini dimulai dengan memberi identitas pada instrumen penelitian yang telah terjawab kemudian memeriksa satu per satu lembaran instrumen pengumpulan data dan 
memeriksa poin-poin serta jawaban yang tersedia.

2. Proses pembeberan (tabulating); tabulasi adalah bagian terakhir dari pengolahan data. Maksud dari tabulasi adalah untuk memasukkan data pada tabel-tabel tertentu dan dapat mengatur angka-angka serta menghitungnya. Yang termasuk ke dalam kegiatan tabulasi ini adalah memberikan skor pada item-item yang perlu diberi skor, memberikan kode terhadap itemitem yang tidak diberi skor, mengubah jenis data dan disesuaikan atau dimodifikasi dengan teknik analisis yang digunakan, serta memberikan kode dalam hubungan dengan pengolahan data jika menggunakan komputer.

3. Penerapan data sesuai dengan pendekatan penelitian; maksud dari poin ini adalah, pengolahan data yang diperoleh dapat disesuaikan dengan pendekatan penelitian atau desain penelitian yang sebelumnya telah dirancang. Dalam hal ini, desain penelitian yang diambil adalah kuantitaif deskriptif

\section{HASIL PENELITIAN DAN PEMBAHASAN}

\section{Hasil Penelitian}

Orang dengan HIV di LSM WISMA terdiri dari 21 orang laki-laki dan 19 orang perempuan. Rentang usia terbanyak berada pada usia 28-37 tahun sebanyak 17 responden. Responden sebanyak 3 orang merupakan anak bungsu atau anak ketiga dari tiga bersaudara dalam susunan anggota keluarganya. seluruh responden beragama Islam. Pendidikan yang ditempuh responden hingga jenjang strata satu, akan tetapi, jumlah terbanyak berada pada jenjang SMA/Sederajat sebanyak 24 orang responden. Pekerjaan terbanyak adalah sebagai ibu rumah tangga, selanjutnya diikuti oleh wiraswasta. Jika dilihat berdasarkan status perkawinan, sebanyak 19 responden adalah belum menikah, 4 responden adalah janda, 1 responden adalah duda, dan sisanya merupkan berstatus menikah. Aktivitas seks berisiko merupkan penyebab HIV terbanyak yang diisi oleh 21 responden. Rentang tahun terkena HIV terbanyak berada pada rentang 2014 hingga 2017.

Situasi orang HIV dalam berinteraksi sosial di lingkungan keluarga mendapatkan total penjumlahan atas jawaban sebanyak 973. Skor tersebut berasal dari jawaban responden yang terdiri dari empat alternatif jawaban yaitu sangat setuju, setuju, kurang setuju, dan sangat tidak setuju yang masingmasing bernilai 4,3,2, dan 1 untuk pernyataan positif dan sebaliknya untuk pernyataan negatif. Skor tersebut menunjukkan bahwa responden memiliki keterlibatan dengan orang lain, keterlibatan dalam kegiatan, maupun ketergantungan dengan orang lain yang tinggi. Hal tersebut terlihat dalam rentang skor 960 sampai dengan 1.280. Situasi di lingkungan keluarga ini menunjukkan bahwa orang dengan HIV mampu 
melakukan salah satu aspek dari interaksi sosial dengan baik dan terlepas dari status mereka yang positif HIV, bukanlah suatu halangan untuk tetap berada dan berbaur dengan keluarga mereka. Jika dilihat, situasi orang dengan HIV dalam berinteraksi sosial di lingkungan keluarga adalah pada gambar berikut.

Situasi orang dengan HIV dalam berinteraksi sosial di lingkungan tetangga mendapatkan skor sebanyak 979. Skor tersebut menunjukkan bahwa responden memiliki keterlibatan dengan orang lain, keterlibatan dalam kegiatan, maupun ketergantungan dengan orang lain yang tinggi ketika berada di lingkungan tetangga. Hal tersebut terlihat dalam rentang skor 960 sampai dengan 1.280 yang termasuk dalam kategori tinggi. Interaksi sosial responden terhadap lingkungan tetangganya membuktikan bahwa mereka dapat tetap bergerak aktif di samping status mereka yang terinfeksi HIV.

Situasi orang dengan HIV dalam berinteraksi sosial di lingkungan teman mendapatkan skor sebanyak 1.101 dari skor total ideal adalah sebanyak 1.440. Interaksi sosial yang dilakukan responden dalam aspek situasi di lingkungan teman sudah baik dan responden dapat dengan mudah bergerak aktif. Selain itu, hasil observasi yang dilakukan peneliti juga menunjukkan bahwa sebagian besar responden memiliki pekerjaan dan membuat responden lebih banyak melakukan interaksi sosialnya.
Mereka dapat saling membahas mengenai berbagai macam hal yang terkait pekerjaan maupun yang tidak terkait dengan pekerjaan. Hasil observasi lainnya menunjukkan bahwa responden menjadi lebih sering melakukan interaksi sosial dengan teman yang berasal dari satu kelompok dukungan sebaya atau teman satu komunitasnya terutama ketika mengadakan sebuah acara/kegiatan. Hal ini menunjukkan bahwa ada suatu ikatan, keterbukaan, dan rasa saling percaya diantara mereka. Aspek situasi ketika orang dengan HIV berinteraksi sosial di lingkungan teman berada pada kategori tinggi, yang dapat dilihat pada gambar dibawah ini.

Situasi orang dengan HIV dalam berinteraksi sosial dengan petugas/pengurus LSM mendapatkan skor sebanyak 906 dari skor ideal sebanyak 1.120. Hal ini menunjukkan bahwa interaksi sosial yang dilakukan dalam aspek situasi sudah baik. Hal ini kemudian didukung oleh observasi yang dilakukan peneliti, dimana orang dengan HIV menunjukkan bahwa mereka dapat terlibat dalam sebuah pembicaraan bersama petugas/pengurus LSM. Mereka membahas mengenai kegiatan yang dilakukan dalam satu hari hingga pembicaraan mengenai tes viraload dan tes CD4. Saat petugas/pengurus LSM menjelaskan mengenai kedua tes tersebut, responden terlihat menyimak dan beberapa kali mengajukan pertanyaan.

Aksi orang dengan HIV dalam berinteraksi sosial di lingkungan 
keluarga mendapatkan skor sebanyak 856 dari skor ideal sebanyak 1.120 , dimana aspek ini terletak pada kategori tinggi. Mereka dapat melakukan kontak mata ketika sedang melakukan perbincangan dengan anggota keluarga, dapat tersenyum dan mendengarkan secara serius apa yang sedang dibicarakan, lebih memilih komunikasi secara tatap muka dibandingkan dengan media komunikasi, anggota keluarganya akan bersalaman, merangkul dan berpelukan ketika sedang berkunjung dan selalu bersikap baik kepada setiap anggota keluarga.

Aksi orang dengan HIV dalam berinteraksi sosial di lingkungan tetangga mendapatkan skor sebanyak 822 dari skor ideal 1.120, aspek ini berada pada kategori sedang. Hasil observasi juga menunjukkan bahwa orang dengan HIV belum maksimal dalam melakukan interaksi sosialnya, dimana ada faktor lain yang menghambat untuk melakukan interaksi sosial dalam aspek aksi, yaitu aktivitas dalam pekerjaan pada masing-masing responden.

Aksi orang dengan HIV dalam berinteraksi sosial di lingkungan teman mendapatkan skor 958 dari skor ideal sebesar 1.280. Hal ini menunjukkan bahwa aksi orang dengan HIV berada pada kategori sedang. Hasil observasi yang dilakukan peneliti juga menunjukkan bahwa beberapa responden kadangkadang hanya bertemu dengan teman satu komunitas saja. Peneliti juga melihat responden ketika sedang berinteraksi sosial di lingkungan temannya terutama dalam aspek aksi terlihat lebih asik dengan handphonenya. Sehingga hal tersebut merupakan salah satu alasan mengapa penilaian terhadap aksi di ligkungan teman berada pada kategori sedang.

Aksi orang dengan HIV dalam berinteraksi sosial dengan petugas/pengurus LSM mendapatkan skor sebanyak 813 dari skor ideal sebanyak 1.120. Aspek ini juga berada pada kategori sedang. Hasil observasi yang dilakukan peneliti terhadap interaksi sosial yang dilakukan responden bersama petugas/pengurus LSM menunjukkan kategori sedang. Hal ini dikarenakan LSM WISMA sedang rehat dari kegiatan rutin. Meskipun sebenarnya masih ada kegiatan lain yang sedang berjalan, akan tetapi tidak semua orang dengan HIV mengikuti kegiatan tersebut. Sehingga rehatnya kegiatan rutin LSM sedikit banyak mempengaruhi interaksi sosial orang dengan HIV terutama dalam aspek aksi.

\section{Pembahasan}

Berdasarkan uraian hasil penelitian di atas, dapat diketahui bahwa dalam setiap aspek yang telah dikemukakan terdapat beberapa permasalahan dari interaksi sosial orang dengan HIV tersebut. Permasalahan interaksi sosial secara umum yang berkaitan dengan aspek situasi dan aksi di lingkungan sosial yang terdiri dari lingkungan keluarga, lingkungan tetangga, lingkungan teman, dan petugas/pengurus LSM dapat dilihat pada uraian di bawah ini. 
a. Belum dapat secara maksimal bercerita kepada suami/istri/orang tua mengenai perlakukan orang lain kepada diri sendiri.

b. Belum sepenuhnya dapat menceritakan masalah pribadi kepada tetangga.

c. Masih merasa kesulitan ketika harus bekerja sama dengan teman-teman dalam menyelenggarakan sebuah kegiatan.

d. Kurang menghabiskan waktu bersama petugas/pengurus LSM yang merupakan orang yang peduli terutama terkait dengan permasalahan HIV.

e. Merasa canggung ketika berinteraksi dengan anggota keluarga yang merupakan orang lebih tua.

f. Merasa canggung untuk berdekatan dan berinteraksi dengan tetangga yang disegani di lingkungan tetangga.

g. Merasa canggung jika berdekatan dengan teman yang berbeda secara usia atau jabatan dalam bekerja dan juga masih merasa kecewa ketika teman menunjukkan gerakan tubuh yang seolah-olah menghindari dirinya.

h. Tidak suka melakukan komunikasi verbal dengan pengurus/petugas LSM terlebih menggunakan telepon/handphone.

Adapun permasalahan secara khusus adalah permasalahan yang berkaitan dengan aspek aksi di lingkungan tetangga, teman, dan petugas/pengurus LSM. Permasalahan khusus dimaksudkan karena pada penilaiannya berada dalam kategori sedang. Berikut ini adalah permasalahan yang dimaksud.

a. Orang dengan HIV masih merasa kesulitan dalam bekerja sama, dimana hal ini penting dilakukan ketika berinteraksi sosial.

b. Orang dengan HIV masih canggung ketika bertemu dengan orang yang lebih tua secara usia maupun memiliki jabatan dalam bidang pekerjaannya, baik itu berada di lingkungan tetangga, teman, atau petugas/pengurus LSM.

Berdasarkan uraian permasalahan di atas, peneliti dapat merumuskan kebutuhan orang dengan HIV dalam berinteraksi sosial yang berada pada aspek aksi di lingkungan sosial.

a. Kebutuhan untuk membiasakan diri dalam bekerja sama dan menyelenggarakan kegiatan di lingkungan sosialnya

b. Kebutuhan untuk membiasakan diri dalam berinteraksi dengan orang yang memiliki perbedaan usia maupun perbedaan jabatan di lingkungan sosialnya

Kedua kebutuhan ini saling berkaitan satu dengan yang lainnya, sehingga, dapat disimpulkan bahwa untuk memenuhi kebutuhan ini dapat diatasi dengan menggunakan media kelompok. Agar dapat terpenuhinya sumber-sumber yang dibutuhkan, peneliti juga kemudian merumuskan analisis sumber yang dapat dijangkau 
oleh orang dengan HIV, diantaranya adalah sebagai berikut.

a. Sumber formal yang dapat membantu dalam peningkatan interaksi sosial orang dengan HIV diantaranya adalah petugas/pengurus LSM WISMA dan kelompok dukungan sebaya yang dinaungi oleh LSM WISMA yaitu Ciamis Care Support.

b. Sumber informal yang dapat digunakan dalam meningkatkan interaksi sosial orang dengan HIV adalah dukungan dari teman, keluarga, pendamping/buddies, dan sesama orang dengan HIV.

c. Dalam hal ini adalah sistem sumber kemasyarakatan yang dapat dijangkau dan dimanfaatkan oleh orang dengan HIV yaitu Puskesmas Imbanagara, Rumah Sakit Umum Daerah Kabupaten Ciamis, Dinas Sosial Kabupaten Ciamis, dan Dinas Kesehatan Kabupaten Ciamis.

\section{KESIMPULAN}

Hasil penelitian menunjukkan bahwa lima dari delapan aspek interaksi sosial orang dengan HIV sudah menunjukkan hasil yang tinggi, sedangkan sisanya menunjukkan hasil yang sedang. Analisis pembahasan terkait dengan interaksi sosial orang dengan HIV lebih difokuskan kepada aspek yang berada dalam hasil yang sedang. Hal ini dilakukan adalah sebagai salah satu upaya pencegahan terhadap interaksi sosial agar tidak menurun. Upaya tersebut dapat dilakukan dengan media kelompok, diantaranya adalah dengan membentuk kelompok bantu diri menggunakan sistem sumber yang sudah diidentifikasi oleh peneliti.

Saran yang peneliti akan sampaikan adalah terkait dengan refleksi penelitian kuantitatif itu sendiri. Penelitian kuantitatif memiliki limitasi atau keterbatasan. Untuk itu, peneliti menyarankan pada penelitian selanjutnya dapat digunakan pendekatan kualitatif deskriptif karena masih banyak informasi unik yang dapat digali lebih mendalam, kemudian juga tidak lupa untuk memisahkan jenjang/stadium HIV karena masing-masing stadium memiliki infeksi oportunistik yang berbeda sehingga sedikit banyak akan tetap berpengaruh kepada interaksi sosial yang dilakukan oleh orang dengan HIV.

\section{DAFTAR PUSTAKA}

Abu Ahmadi. 2009. Psikologi Sosial. Jakarta: Rineka Cipta.

Adi Fahrudin. 2012. Pengantar Kesejahteraan Sosial. Bandung: PT. Refika Aditama.

Bambang Syamsul Arifin. 2015. Psikologi Sosial. Bandung: Pustaka Setia.

Burhan Bungin. 2014. Metode Penelitian Kuantitatif. Jakarta: Kencana Prenadamedia Group.

Fitrilia Silvianti. 2009. Mengenal HIV/AIDS. Jakarta: PT. Perca.

Gallant, Joel. 2010. 100 Tanya-Jawab mengenai HIV dan AIDS. 
Jakarta: PT. Indeks. Versi Terjemahan.

Garvin. Tentang Group Work. STKS Bandung.

Lina Favourita Sutiaputri, dkk. 2014. Modul Praktik Pekerjaan Sosial dengan HIV/AIDS. Bandung: Pusat Kajian dan Layanan Hiv/AIDS STKS Bandung

Maya Yulianti. 2016. Pengaruh Interaksi Sosial Siswa Terhadap Terbentuknya KelompokKelompok Pergaulan Di SMK Nusantara Desa Madukoro Kecamatan Kotabumi Kabupaten Lampung Utara. Universitas Lampung: Fakultas Keguruan dan Ilmu Pendidikan

Pincus, Allen dan Anne Minahan. 1973. Social Work Practice: Model and Method. Itasca, Illionis: FF Peacok Publisher.

Sarlito W. Sarwono. 2010. Pengantar Psikologi Umum. Jakarta: Rajawali Pers.

Setyoadi dan Endang Triyanto. 2012. Strategi Pelayanan Keperawatan bagi Penderita AIDS. Yogyakarta: Graha Ilmu

Slamet Santoso. 2010. Teori-teori Psikologi Sosial. Bandung: Refika Aditama.

Soerjono Soekanto. 2012. Sosiologi: Suatu Pengantar. Jakarta: PT Grafindo Persada. 155

Sudjana. 2005. Metode Statistika. Bandung: Tarsito

Sugiyono. 2011. Metode Penelitian Kuantitatif, Kualitatif, dan $R \& D$. Bandung. Alfabeta.

Subhanudin Husen. 2015. Interaksi Sosial Orang dengan HIV/AIDS (ODHA) dalam Pemudaran Stigma. Universitas Pendidikan Indonesia.
Suharsimi Arikunto. 2014. Prosedur Penelitian: Suatu Pendekatan

Praktik.J akarta: Rineka Cipta.

Susilowati, E., \& Dewi, K. (2019).

Living Experience Of Women With

Hiv/Aids In West Java

Indonesia. Indonesian Journal of

Social Work, 3(1).

Yense Eldiana Dhita. 2011. Hubungan Interaksi Sosial Teman Sebaya dengan Tingkat Kemandirian Anak Usia Prasekolah di TK ABA Kecamatan Tanggul Kabupaten Jember. Universitas Jember: Program Studi Ilmu

Keperawatan

Yoel. 2014. Interaksi Sosial Anak Disabilitas Netra di SLBN-A Bandung. Sekolah Tinggi Kesejahteraan Sosial (STKS) Bandung: Program Studi Pekerjaan Sosial.

Sumber Bacaan Lain:

http://www.aidsindonesia.or.id/list/7/ Laporan-Menkes diakses pada 10 Agustus2016 pukul 05.15 WIB http://www.koransindo.com/news.php? $r=4 \& n=3 \&$ date $=2016-07-27$ diakses pada

9 Agustus 2016 pukul 03.34 WIB http://www.kemenpppa.go.id/index.p hp/page/read/30/385/kasus-hiv-aidsdiindonesiameroket?EsetProtoscanCtx $=$ bfbf9e8 diakses pada 27 Desember 2016 pukul 23.52 WIB media.kemsos.go.id/images/930ART IKEL_ODHA_Harry_Hik.pdf diakses pada 9 Januari 2017 pukul 18.33 WIB

Spiritia. 2014. Dasar HIV \& AIDS. Melalui http://spiritia.or.id/art/bacaart.php?art no=1001 . Diakses pada 14 Januari 2017 pukul 23.21 WIB 